\title{
The Unbearable Settler West in The Ballad of Buster Scruggs
}

\section{Lahti, Janne}

Routledge

2020-07

Lahti , J 2020 , The Unbearable Settler West in The Ballad of Buster Scruggs . in J Lahti \& R Weaver-Hightower (eds) , Cinematic Settlers : The Settler Colonial World in Film . vol. 2020 , Routledge , USA , pp. 77-86 . https://doi.org/10.4324/9781003057277-6

http://hdl.handle.net/10138/339864

https://doi.org/10.4324/9781003057277-6

acceptedVersion

Downloaded from Helda, University of Helsinki institutional repository.

This is an electronic reprint of the original article.

This reprint may differ from the original in pagination and typographic detail.

Please cite the original version. 


\section{The Unbearable Settler West in The Ballad of Buster Scruggs}

Janne Lahti

Abstract: The anthology The Ballad of Buster Scruggs (2018) offers Western settler colonial narratives in very typical scenarios. Yet, it also challenges classic settler colonial narrative outcomes, but without managing to overcome the overarching whiteness of the reel settler West. This essay argues that the settler West of The Ballad of Buster Scruggs comprises a type of emotional community marked by purposelessness, randomness, and sadness. In short, this settler West is a twisted space, violent and cold. In fact, it is pretty unbearable. Yet, it is also unbearably white, hiding the ethnic diversity of the historic West and thus, once again, reaffirming the filmic settler colonial West as a white space, although this time as a twisted one. In the end, we still have a depiction of the white settler experience told from the white settler perspective and through white settler eyes.

The Ballad of Buster Scruggs (2018), from Joel and Ethan Coen, frames the nineteenth century American West through six short stories. They offer narratives in very typical Western scenarios. We have cowboys, gun fighters, bank robbers, prospectors, showmen, farmers, and even a vulnerable pioneer lady in need of rescue. We also get wagon trains, frontier towns, Indian attacks, and stagecoach rides - the usual Western tokenisms applied to characterize frontier and pioneer life and the advance of white civilization. It seems that only the US Cavalry and the railroads are missing from the prototypical Western imagery. ${ }^{1}$ However, while The Ballad of Buster Scruggs operates in classic settler colonial narrative settings, it does not offer typical settler colonial narrative solutions.

Many commenters have interpreted the movie as a dark humor-blitz on Western tropes. One observant critic notes that the film advances "giddy Western revisionism" laughing at the expense 
of old Western legends, those "titanic heroes" still eagerly consumed by American politics and society as historical truths. ${ }^{2}$ The film does more than "giddy," however. This essay will argue that it destabilizes the traditional narrative storyline of the Western and thus subverts the settler experience on the silver screen, recalibrating the settler West as emotionally twisted, as a sad, violent, and purposeless space. Here the settler lives random lives, wanders aimlessly, and dies abruptly, never overcoming nature, taming the land, or pacifying the violent frontier town; there is no "settling down" or starting a heterosexual nuclear family. The settler finds no righteousness, no justice, and no opening to enter his "house justified," to borrow the famous quote from director Sam Peckinpah's Ride the High Country (1962). In Peckinpah's classic depiction of Western masculinity, a former gunfighter Steve Judd (Joel McCrea), out of time and out of luck, wants to do the right thing and find redemption in life through honest work. He seeks no earthly riches, peer admiration, or power, but states that "All I want is to enter my House justified." There is no such prospect in The Ballad of Buster Scruggs. Its settler West is too unbearable for that.

That the emotional community in The Ballad of Buster Scruggs conveys a twisted settler West can be interpreted as undermining the legitimacy of archetypical historical narratives of America's western expansion, as subjecting settler penetration and the taking of the land to criticism while stripping the white settlers of their aura of virtue and respectability. Yet, the movie never goes as far as to question the US settler colonial project in the West. There is no narrative of individual settlers turning back, and there is no giving back of the land. Importantly, the settler West remains unbearably white, as if the settler colonial experience would only concern white people. When hiding the ethnic diversity of the historic West, this film reaffirms the prevailing public perceptions of settler colonial West as a white space, although now an emotionally twisted one. In the end, we still have a depiction of the white settler experience, no matter how ugly, told from the white settler perspective and through white settler emotions. 
This essay contributes to an ongoing conversation on the ways in which the Western normalizes whiteness, and justifies and questions domination ${ }^{3}$ by arguing that the settler West of The Ballad of Buster Scruggs constitutes an emotional community defined by purposelessness, randomness, and futility. As its analytical framework, this article employs the idea of "emotional communities" from historian Barbara H. Rosenwein. ${ }^{4}$ While she uses the notion to refer to the systems of feeling that historical social communities express and share in real life, here emotional community refers to the kind of narrative strands of feeling that constitute the settler West on screen. The Ballad of Buster Scruggs represents the West as a specific type of twisted and unbearable emotional community marked by fear and sadness, the coldness and the randomness of settler existence.

The first part of this essay briefly discusses the Western as a prototypical settler colonial narrative and situates The Ballad of Buster Scruggs into the genre. The next section highlights how the first three episodes in The Ballad of Buster Scruggs represent the settler West as an emotional community through narratives solutions that destabilize our expectations. The last section zooms into the ways the familiar themes of land and the settler get similarly undermined in the final three episodes, while discussing what it indicates that whiteness continues to define the settler West.

\section{The Western as Settler Colonial Formula}

The American film genre commonly called "the Western" has been extensively studied and debated for decades already and by scholars in multiple disciplines. As literary scholar Scott Simmon notes "There are a number of ways to write about the relationship between the Western film and the [historic] West, each full of compromises." He goes on to state that it has been widespread among scholars to complain about Hollywood's distortions over what actually happened in the West, or to make a clear-cut difference between the real and reel West. ${ }^{5}$ Yet, at the same time it has been very common for scholars to argue that the Western is intimately American, 
and thus integral to US national identity and history, giving meaning and signifying what makes the US exceptional, what defines the national experience. The lure of the West has been its settler colonial narrative of advancement, mobility, and dynamism, which links individual triumph with community morals and prosperity. The Western settler narrative at its core has promoted an ideal of overcoming struggles, demonstrating one's true moral respectability and physical mettle, coming together (often as a nuclear family), and building a brighter future. Like literary scholar Jane Tompkins argues, the West and the Western function as a "symbol for freedom, and of the opportunity for conquest," as a place for "self-transformation."6 This sounds awfully settler colonial.

Offering the kind of settler colonial narrative that Americans could accept, the Western can also be understood as a prototype for a global settler colonial narrative. While most scholars who have discussed the Western have shied away from making the connection between the genre and settler colonialism, those scholars working on settler colonial cinemas, including more than a few in this book, seem to consider the Western as the formula and the standard to which to compare other settler colonial narratives in places around the world. Classic elements of the Western have proven highly portable - whether seemingly unstoppable white settler conquest, mobility as triumphant struggle through epic landscapes, the setting up of communities on "free land," and depictions about settler masculinity, individualism, and community. Its iconography includes tropes familiar to settler narratives worldwide. There are the Natives, frequently cast as (noble or ignoble) savages whose "role is to be the obstacle over which the whites must ride," as film historian Edward Buscombe notes. ${ }^{7}$ There are traders, prospectors, cowboys, and gunfighters, epitomes of the violent edge of settler incursion. While they may hail from different class or national backgrounds, the settlers are nearly always white. The kind who build towns, schools, and churches are defined as the "common people," the universal ideal. It is they who are engaged in far-settlement, "discovering" the land, making it blossom, and claiming it as theirs and for their offspring to come. How the West 
Was Won (1962, dir. John Ford, Henry Hathaway, and George Sherman) is the classic film anthology showcasing this fantasy at its most epic dimensions and unapologetic tone. The film provides a multigenerational saga of settler colonialism that sweeps the continent, reinvents the land, and gives meaning to its peoples. This kind of archetypal Western settler colonial narrative is grounded on notions of advance forward and on a didactic of destruction, substitution, and rebirth: the Natives must step aside and/or disappear, by force if needed; the settlers must arrive to a particular destination, claim, occupy, and "settle" it; and while the settlers transplant their values, norms, and societies with them, they and the land itself, are also remade and regenerated as result of the settler colonial process. ${ }^{8}$

The Ballad of Buster Scruggs skirts all of this. Although it operates in a characteristically settler colonial setting, it challenges the exemplary settler colonial outcomes. While the landscapes stand as epic and the central archetypes are present, the storylines show no overcoming of natural obstacles, no taming of the land, no subjugation of Natives, no building of civilization, no personal success stories, or no triumph of good against evil by the settlers. Films like Arthur Penn's Little Big Man (1970) or Sam Peckinpah's The Wild Bunch (1969) mounted a furious attack on triumphant settler narratives, epitomized in films such as They Died with Their Boots On (dir. Raoul Walsh, 1941) or John Ford's “cavalry trilogy," Fort Apache (1948), She Wore a Yellow Ribbon (1949), and Rio Grande (1950), by depicting a racist and bloody settler world built on exploitation and genocidal violence. Yet, The Ballad of Buster Scruggs goes beyond this more traditional criticism of the settler West as racist and violent when depicting the settler West as an emotional dead end, as dreary, pointless, and short on purpose or meaning.

\section{The Settler, Interrupted}

The Ballad of Buster Scruggs' opening scene depicts a lone white rider in Monument Valley. By commencing in this epic western location made famous by numerous John Ford films, including 
the The Searchers (1956), as well as by Sergio Leone's revisionist epic Once Upon a Time in the West (1968), The Ballad of Buster Scruggs immediately situates itself in the heart of the settler colonial narrative canon. It appears to grasp for authenticity and emotional continuity by locating itself in the most iconic of reel West places. It is here that settler farming communities are bound to the earth and families are tormented by violent Comanche attacks and the killing and kidnapping of innocent white children - as in The Searchers. It is here that the honorable and brave US Cavalry punish the wily and savage Apaches, making the land safe for pioneer settlers - as in Fort Apache and Rio Grande. It is here that the settler wagon trains reach the promised land, as in Wagon Master (dir. John Ford, 1950) And it is here that the railroads, with all their corruption, greed, and violence, bring settler civilization to tame the land - as in Once Upon a Time in the West. For filmic settler narratives, Monument Valley embodies the greatest settler myths of white triumph.

Yet, we soon discover that this is not your usual settler story as the narrational archive this film mobilizes toys with and destabilizes our expectations of what Western settler narratives should contain. Our lone rider in the Monument Valley is Buster Scruggs (Timothy Blake Nelson), a singing cowboy and a narcissistic dandy dressed in white. He does not look or sound very masculine. In short, he is no John Wayne, Randolph Scott, Joel McCrea, Clint Eastwood, or even Kevin Costner. Unlike the silent, sturdy, Western hero and antihero, Buster waffles a lot and sings aloud of his longing for cool water and green grass, both of which are in scarce supply during his day journey. Singing of water in a desert is another way the film undercuts the settler narrative and makes fun of it. Of course, desert sand did little to prevent previous generations of filmmakers setting up settler farming utopias in Monument Valley. Perhaps they took their cues from the famous nineteenth century settler myth that "rain follows the plough." Well it didn't, not in real life anyway, as the Dust Bowl in the 1920s aptly demonstrated. Here also the song about "the big green tree, where water is running free and it is waiting there for you and me" stands in stark contrast to the natural surroundings of parched rocks and dust under the scorching sun. There is no water, no 
green trees, or in fact anything green in sight. Neither does Buster encounter any settler families or farms, only a forlorn tavern filled with dirty and desperate mischiefs prone to violence, and soon dead from Buster's pistols. Parodying and subverting Western settler clichés but also adhering to them with the gunfight in the tavern and by setting itself in Monument Valley in the first place, these opening moments show that this settler story is not going to end up the way one thinks.

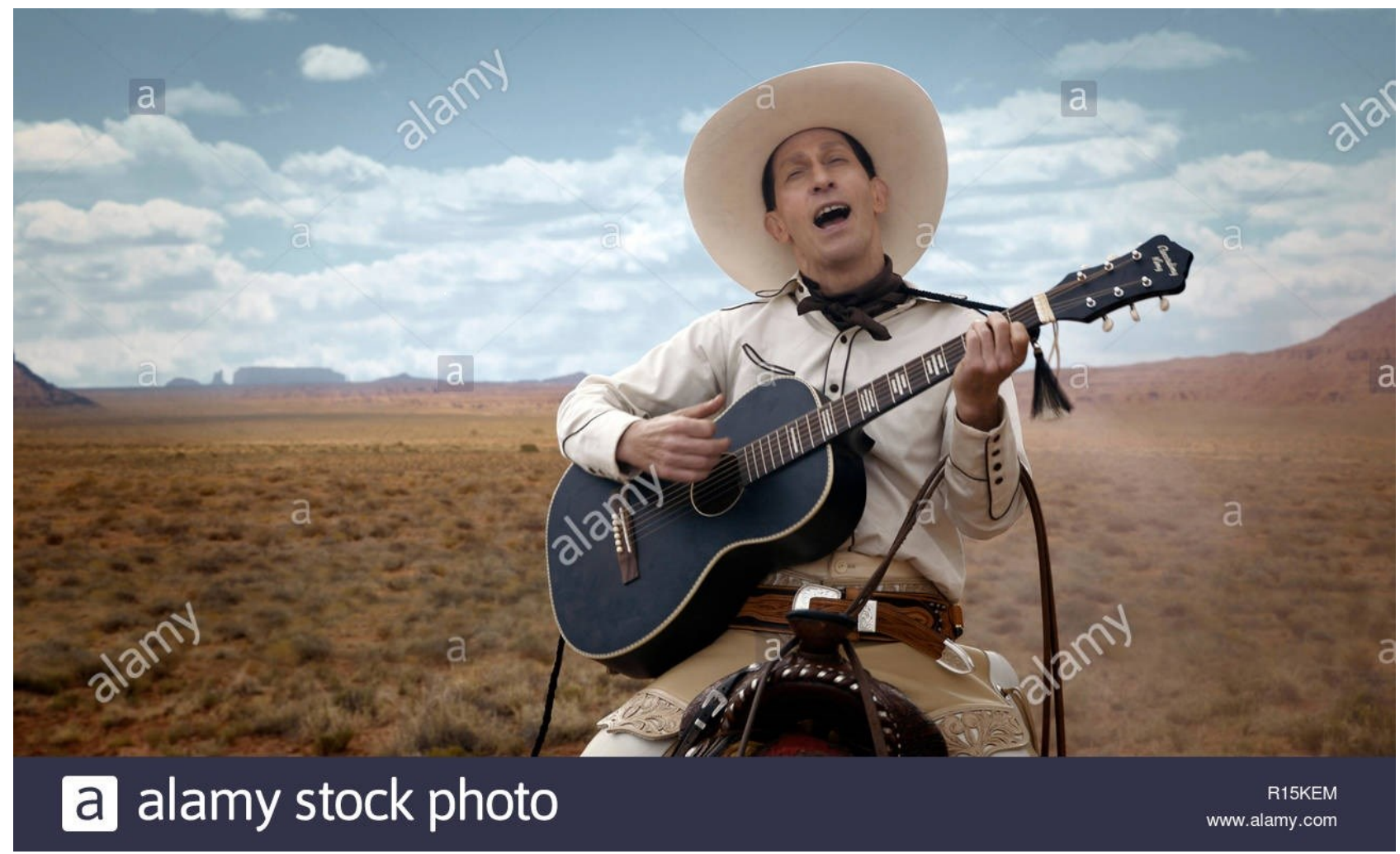

Figure 1. Buster Scruggs, the singing settler dreaming of water and green grass while making his way in Monument Valley.

As the film progresses, it becomes evident that, while Buster seems very frail and likeable, jolly and talkative, he is actually a psychotic killer, as deadly a man as there is, likely made that way by the wickedness of the settler West he occupies. Showing no remorse, or justification, Buster kills men around him until he himself is gunned down in the middle of the street by another gunfighter, dressed in black, and also singing. We witness Buster's ghost ascending to heavens, singing about 
the end of a cowboy's life, and in hopes of going to a better, kinder, and more honest place, where men can leave behind "all the meanness in the used-to-be," referring to all the violence that consumes the settler society.

This kind of random and violent emotional community also permeates the second story "Near Algodones." Here the protagonist, simply dubbed as "Cowboy" (James Franco), is desperate and out of luck as tragedy and violence consumes his life and throws him from one calamitous situation to another in arbitrary manner. First he engages in a futile robbery attempt of an isolated bank in the middle of the open prairie, only to have the teller (Stephen Root) shoot at him and chase him out in hail of bullets, until knocking him cold with the end of his rifle. The Cowboy wakes with a rope around his neck, facing a white settler posse eager to distribute some peer justice after what they claim had been "a fair trial" under the open sky while the Cowboy was knocked unconscious. This form of arbitrary and merciless "justice," one of them remarks, is "like we do here in New Mexico." Yet, the Cowboy is saved by a random, unexplained, Indian attack, where the other whites are slayed. It is not that the Indians are there to rescue the Cowboy, but that he just happens to be the only one white man they don't kill, and for no apparent reason. It is just another indicator of the randomness of this settler West. It is also difficult to say why the Indians are there. They are angry, probably. It is as if they stem from a landscape of violence, where people appear to be naturally mean and malevolent towards each other. This emotional community seems to have little room for logic in its saturated violence.

Saved by random violence, the Cowboy is then rescued from the end of the rope (where he was put by the posse and left hanging by the Indians) by another cowboy (Jesse Luken) passing by. This brief glimpse of hope and comradery soon gives way to despair as this second cowboy turns out to be a rustler. While he escapes, our Cowboy gets caught by a posse and loses his life when hanged in a public courtyard of a settler community. So, in this second story also the protagonist lives a life of violence and dies a random death. The narrative style offers no explanations for why 
he was robbing the bank in the first place, why the Indians attacked, who the rustler was, or of the events - arrest, jailing, and trial - that led to the gallows. Everything seems random and lives pointless, as if being called by a roll of some cosmic dice where the protagonist has little to say. What is by now clear is that this settler West is not grounded on justice, heroism, or hope. It seems to offer no window for prosperous futures or chance of settling down. The most merciless example, however, of the meaninglessness and soullessness of this rotten settler world is the third story, "Meal Ticket."

This narrative follows a touring duo traversing wintry mountains and performing in small settler villages, "a freak show" consisting of an "Impresario" (Liam Neeson) and the "Artist," a handicapped - quadriplegic - boy (Harry Melling). The Artist is devoid of all of his limbs, and thus totally reliant on the Impresario for this daily survival. This is no friendship, or even an odd couple, just two sad and lonely men begging for their livelihood by performing outdoors to small crowds (consisting of as few as three people on one occasion). They hardly talk to each other or to anyone else, except on stage where the boy recites, in a monotonous fashion - and thus seemingly bored out of his senses - the same repertoire that includes lines from, for example, Shakespeare, the Bible, and the Gettysburg Address. There is no display of any kind of affection between the men, or between them and their audiences. While present in the settler villages, they remain perennial outsiders and have very little actual interaction with other people outside the show. Their life seems endlessly repetitive, dull and dreary. The only solace is when they together visit a brothel. While the Impresario enjoys some intimacy, he denies this from the Artist and makes the boy sit on the floor facing the wall while he has sex with a prostitute. And again it all ends abruptly, the Impresario dumping the Artist into a freezing and snowy river gorge to die, without any explanation. There is no preceding dispute, or clash between the men. It is heartless act in a heartless settler world.

\section{The Land, So White}


So far, all the principal cast of the vignettes discussed have been white men, and this changes only slightly in the last three episodes, "All Gold Canyon," "The Cal Who Got Rattled," and "The Mortal Remains." The three first episodes pay hardly any attention to the land, although in numerous classic Westerns - Shane (dir. George Stevens, 1953), The Big Country (dir. William Wyler, 1958), and El Dorado (dir. Howard Hawks, 1967) among them - land use, ownership, and disputes form the central theme, while in others dealing with indigenous elimination, land is also typically forming the framework for the plot. After all, settler colonialism is fundamentally about the land and who gets it. "All Gold Canyon," as the title suggests, does shift focus to the land, a lush pristine valley teeming with wildlife and full of magnificent trees, but here the land clearly offers a canvas for one settler's (Tom Waits) obsession. This lonely old prospector, who appears to be alone in the valley, futilely digs a hole after hole on this green soil, coming up empty handed. Delirious, he mumbles to the gold he presumes lies hidden underground that "I'm gonna get you." When he finally makes a major strike, he instantly gets shot in the back by some random stranger. Another arbitrary, sad end? Not this time, as the prospector shoots back, kills his assailant, and then leaves the valley. As he departs, however, we realize he is still fixating over gold. Consumed by his personal creed, he intends to return soon, probably with more supplies. This settler remains driven by his mania to benefit from the land although this almost cost him his life and for the sake of which he killed a man. There is no remorse or reflection, no personal growth or redemption. As a viewer, at this point of the film you expect nothing less from this cutthroat settler realm.

The twisted emotive tensions of sadness, arbitrariness, and the cutthroat get another spin in what at first looks like a predictable Western settler colonial narrative strand, the journey to promised land in "The Cal Who Got Rattled." Much like in classic Western narratives, evidenced in such films as Wagon Master and Westward the Women (dir. William A. Wellman, 1951), the wagon train party here is composed of moral common people, white heterosexual homesteaders who face ordeals to overcome, obstacles to beat, and struggles that build character. This story typically would 
show the settlers' sweat and blood spilled to reach the promised land make them belong as if indigenous to the place. Settlers would be righteous, their cause just, and they would prevail. ${ }^{9}$ Not so here. The main protagonist is a frail, shy, helpless, and hapless Alice (Zoe Kazan), a female character that makes a mockery even of the stereotype of a fragile Victorian lady by being even more so. She loses her overbearing brother along the way, has problems with her aide, is scared of pretty much everything, gets interested in a man, meets attacking Indians, and dies by her own hand, maybe accidentally but probably shooting herself because of being so utterly petrified. Apparently, the movie's message here seems to be that this callous settler West has no room for middle-class, decent, women. Interestingly, there being no women indicates -as already suggested by the random violence and the sad heartlessness of human relationships - that this settler West might not last: no women, no offspring, no settler futures. But does it have any kind of futures?

Once again the Indians have attacked without much reason or logic - as they often do in traditional Western narratives. And that is all they do in many Western films, including The Ballad of Buster Scruggs. When viewing The Ballad of Buster Scruggs as a critique of settler colonialism, its pervasive whiteness represents its principal fault. Certainly, the film takes the canonic settings and uses them often for undermining the common narrative. Here the frontier does not make for better humans, adversity is not overcome, and challenges don't bring out the best of settlers, let alone create a sense of mission, community, or destiny. The settler present is bleak, and so is the future, although nobody seems to give much thought to it, or to have much of one.

However, exogenous and indigenous alterities have disappeared and only settlers remain they are normal, although they may not have a future. We could think that this settler society may be in crisis, but then again there is little indication that it is: crazy may be its normal. The settler would seem illegitimate here, of not belonging. But there is nobody else. The film is fundamentally settler-oriented, settler-directed, and settler-centered. There are not even any settler-indigenous exchanges, except two episodes of random violence where the Indians attack, kill, and disappear- 
all without any explanation or voice (yelling does not count as a voice here). Of course, this is a very characteristic indigenous role in Westerns. ${ }^{10}$

Also predictable is that no other non-whites are seen on screen, and therefore have no voice. Reinforcing antiquated perceptions of racial and gender homogeneity, the film hides the ethnic diversity of the historic West, suppressing an important part of its history and thus reflecting today's discussion of American identity, borders, and inclusion. ${ }^{11}$ Westerns have traditionally reinforced stories of a "white West" rather than exposing the historical diversity of races and ethnicities in the West. For instance, by watching Westerns one would never know that the Chinese were the biggest ethnic group in the California Gold Rush and that some Native Americans such as the Comanches were active expansionists and empire-builders. One is also at odds to find Hispanic or African American cowboys in the numerous cowboy films, including Red River (dir. Howard Hawks, 1948), Cowboy (dir. Delmer Daves, 1958), or Wild Rovers (dir. Blake Edwards, 1971). While whiteness comes out as deformed, ugly, and sad, it is still all there is in this settler West of The Ballad of Buster Scruggs. As a result, the West as an emotional community comes across as both unbearable and unbearably white. By skirting the discussion, by keeping silent instead of exposing and questioning the Western's settler colonial mechanisms of elimination and erasure, the film in fact hides the settler colonial tendency to displace - anthropologist Patrick Wolfe's elimination of Natives - and the tendency of settlers to indigenize themselves in order to legitimize their rule. ${ }^{12}$

\section{Conclusion}

By the time the last episode of The Ballad of Buster Scruggs, "The Mortal Remains" begins, we have come a long way from Monument Valley. This episode shows a stagecoach ride from nowhere to nowhere, there are no dangers or Indian threats to overcome, or unite the passengers -as in the classic Stagecoach (dir. John Ford, 1939). This time the bickering passengers - a trapper, a 
gambler, two bounty hunters, and a middle-class lady, just keep annoying and arguing each other over life's meanings. These people seem to share nothing in common and reach no harmony. Suitably, their journey ends not in a thriving settler community. Instead, the end comes sudden, and at a doomed-looking, forlorn hotel, isolated and uninviting in a dark lonely night. That the bounty hunters have hauled a dead corpse they have killed in cargo, and end up carrying it to their hotel room for the night, brings little solace and if anything makes the settler condition look bleaker. This final episode seems to reaffirm the movie's message of settler colonialism as a callous enterprise, a failure, where the settler experience is consumed by loneliness and purposelessness. It is hallow and haunted world the settler has built. But this episode also shares the film's major shortcoming, the stagecoach cast is, once more, all white.

Surely, the settler experience in The Ballad of Buster Scruggs is far from an archetypal settler colonial fantasy. Rather it has the feel of an anti-fantasy, a grim, heartless, and violent panorama tainted by the greed and selfishness of the settlers. This is a settler space that appears emotionally bankrupt, degenerate, and desperate. It is an aimless emotional community filled with dread, sadness, fear, and violence. It is also a haunted space of failure, seemingly short on any prosperous settler futures. Yet, it is an unbearable settler experience that remains unbearably white in its cast and its perspectives, reiterating the settler colonial West as a white space. What this means is that while The Ballad of Buster Scruggs undercuts the Western canon by telling twisted accounts in typically settler colonial scenarios, it never goes as far as to counter the racial blueprints of the canonic narrative. The settler wagons apparently cannot be turned around, and this is the tragedy of it all. The settler is condemned to live in the legacies of his sins, enduring the futility and arbitraries of violence in a West that has lost its moral and communal bearings.

\footnotetext{
${ }^{1}$ On the Western imagery, see Michael Coyne, The Crowded Prairie: American National Identity and the Hollywood Western (London: Tauris, 1997); Jennifer L. McMahon and B. Steve Csaki,
} 
eds., The Philosophy of the Western (Lexington: University Press of Kentucky, 2010); Jane Tompkins, West of Everything: The Inner Life of Westerns (Oxford: Oxford University Press, 1993).

${ }^{2}$ Richard Brody, 'Review: The Coen Brothers' 'The Ballad of Buster Scruggs' is Six Giddy, Cruel Twists on the Western,” The New Yorker, November 14, 2018,

https://www.newyorker.com/culture/the-front-row/review-the-coen-brothers-the-ballad-of-busterscruggs-is-six-giddy-cruel-twists-on-the-western (accessed January 28, 2020).

${ }^{3}$ Robert B. Pippin, Hollywood Westerns and American Myth: The Importance of Howard Hawks and John Ford for Political Philosophy (New Haven: Yale University Press, 2010); Jonna Eagle, Imperial Affects - Sensational Melodrama and the Attractions of American Cinema (London: Rutgers University Press, 2017); Julia Leyda, “Black-Audience Westerns: Race, Nation, and Mobility in the 1930s," in Julia Leyda, American Mobilities: Geographies of Class, Race, and Gender in US Culture (Bielefeld: transcript Verlag).

${ }^{4}$ Barbara H. Rosenwein, "Worrying about Emotions in History," American Historical Review 107.3 (2002), esp. 842-843. See also Barbara H Rosenwein and Riccardo Cristiani, What is the History of Emotions? (Cambridge: Polity, 2018), 26-62.

${ }^{5}$ Scott Simmon, The Invention of the Western Film: A Cultural History of the Genre's First HalfCentury (Cambridge: Cambridge University Press, 2003), xiii.

${ }^{6}$ Tompkins, West of Everything, 4. On the Western and American identity, see also Mary Lea Bandy and Kevin Stoehr, Ride, Boldly Ride: The Evolution of the American Western (Berkeley: University of California Press, 2012); John E. O'Connor and Peter C. Rollins, "Introduction: The West, Westerns, and American Character," in Rollins and O'Connor, eds., Hollywood's West: The American Frontier in Film, Television, and History (Lexington: University Press of Kentucky, 2005), 1-34; Patrick McGee, From Shane to Kill Bill: Rethinking the Western (Oxford: Blackwell, 2007); Lee Clark Mitchell, Westerns: Making The Man in Fiction and Film (Chicago: University of 
Chicago Press, 1996).

${ }^{7}$ Edward Buscombe, 'Injuns!': Native Americans in the Movies (London: Reaktion Books, 2006), 81.

${ }^{8}$ Janne Lahti, "Settler Passages: Mobility and Settler Colonial Narratives in Westerns," Journal of the West 56.4 (2017), 67-77.

${ }^{9}$ On settler wagon train narratives in Westerns, see Lahti, "Settler Passages."

${ }^{10}$ On depictions of Native Americans in Westerns, see Angela Aleiss, Making the White Man's Indian: Native Americans and Hollywood Movies (Westport, Con.; Praeger, 2005); Jacquelyn Kilpatrick, Celluloid Indians: Native Americans and Film (Lincoln: University of Nebraska Press, 1999); José Armando Prats, Invisible Natives: Myth and Identity in the American Western (New York: Cornell University Press, 2002); Janne Lahti, "Silver Screen Savages: Images of Apaches in Motion Pictures,” Journal of Arizona History 54.1 (2013), 51-84.

${ }^{11}$ For new research on the racial diversity of the historic American West, see, among many others, Erika Lee, The Making of Asian America: A History (New York: Simon \& Schuster, 2016); Kelly Lytle Hernández, City of Inmates: Conquest, Rebellion, and the Rise of Human Caging in Los Angeles, 1771-1965 (Chapel Hill: University of North Carolina Press, 2017); Manu Karuka, Empire's Tracks: Indigenous Nations, Chinese Workers, and the Transcontinental Railroad (Berkeley: University of California Press, 2019).

${ }^{12}$ Patrick Wolfe, "Land, Labor, and Difference: Elementary Structures of Race.” American Historical Review 106.3 (2001), 866-905. 